\title{
Simalikalactone D, a Potential Anticancer Compound from Simarouba tulae, an Endemic Plant of Puerto Rico
}

\author{
Belmari Mendez ${ }^{1}$, Jeyshka Reyes ${ }^{2}{ }^{\circ}$, Isabel Conde ${ }^{2}{ }^{(}$, Zulma Ramos $^{3}$, Eunice Lozada ${ }^{4}(\mathbb{D}$, \\ Ailed M. Cruz ${ }^{2}$, Gabriela Asencio ${ }^{3}$, Augusto Carvajal ${ }^{1}$, Suranganie Dharmawardhane ${ }^{2}(\mathbb{D}$, \\ Dalice M. Piñero-Cruz ${ }^{5}$ (D) Eliud Hernández ${ }^{3}$, Pablo Vivas ${ }^{2}$ and Claudia A. Ospina ${ }^{6, *(D)}$ \\ 1 Natural Sciences Program, University of Puerto Rico at Cayey, Cayey 00736, Puerto Rico; \\ belmari.mendez@upr.edu (B.M.); augustocarvajal@gmail.com (A.C.) \\ 2 Department of Biochemistry, University of Puerto Rico, Medical Sciences Campus, San Juan 00936, \\ Puerto Rico; jeyshka.reyes@upr.edu (J.R.); isabelconde031@gmail.com (I.C.); \\ ailed.cruzcollazo@upr.edu (A.M.C.); su.d@upr.edu (S.D.); pablo.vivas@upr.edu (P.V.) \\ 3 Department of Pharmaceutical Sciences, University of Puerto Rico, School of Pharmacy, San Juan 00936, \\ Puerto Rico; zulma.ramos1@upr.edu (Z.R.); gabriela.asencio1@upr.edu (G.A.); \\ eliud.hernandez@upr.edu (E.H.) \\ 4 Department of Biology, University of Puerto Rico, Río Piedras Campus, San Juan 00936, Puerto Rico; \\ eunice.lozada@upr.edu \\ 5 Department of Chemistry, University of Puerto Rico, Río Piedras Campus, San Juan 00936, Puerto Rico; \\ dalice.pinero@upr.edu \\ 6 Department of Chemistry and Physics, Universidad Ana G Mendez, Gurabo 00778, Puerto Rico \\ * Correspondence: claudiaandreaospina1@gmail.com or ospinac1@uagm.edu; Tel.: +1-787-743-7979 (ext. 4891)
}

Received: 24 November 2019; Accepted: 6 January 2020; Published: 11 January 2020

\begin{abstract}
Species of the genus Simarouba have been studied because of their antimalarial and antileukemic activities. A group of oxygenated terpenes called quassinoids have been isolated from species of the Simarouba genus, and are responsible for its therapeutic properties. We hypothesized that Simarouba tulae, an endemic plant from Puerto Rico, is a natural source rich in quassinoid compounds with anticancer activity. The leaves were processed and extracted with solvents of different polarities. The extracts were screened for their antiproliferative activity, and it was shown that the chloroform extract was the most active extract. This extract was purified using different chromatographic techniques to afford the quassinoid simalikalactone D (SKD). This compound was further characterized using NMR and X-ray diffraction analysis. A reassessment of original structural assignments for SKD is proposed. SKD showed high cytotoxicity activity, with an $\mathrm{IC}_{50}$ of 55, 58, and $65 \mathrm{nM}$ in A2780CP20 (ovarian), MDA-MB-435 (breast), and MDA-MB-231 (breast) cell lines, respectively. Exposure to SKD led to 15\% inhibition of the migration of MDA-MB-231 cells.
\end{abstract}

Keywords: Simarouba tulae; quassinoids; simalikalactone D; breast cancer; ovarian cancer; medicinal plants; migration

\section{Introduction}

Cancer is a public health problem characterized by the abnormal growth of cells in the body. The World Health Organization (WHO) has estimated that the number of new cancer cases in the world will increase in the next two decades from 18.1 million in 2018 to 29.5 million in 2040 [1]. Therefore, there is a need for more research directed to prevention, treatment, and the discovery of new specific and non-toxic therapeutic agents for this disease. A practical strategy in the drug discovery area is exploring the potential of the chemical constituents isolated from medicinal plants [2-4]. 
The overall goal of the present research was to discover and characterize compounds from medicinal plants with potential therapeutic application in the treatment of cancer. Specifically, the anticancer properties of Caribbean plants have been less studied than those of plants from Africa, Asia, and Europe [5]. Since Simarouba species are rich in bioactive quassinoid compounds, the main objective was to evaluate the antiproliferative potential of extracts and pure compounds from the leaves of S. tulae.

The Simaroubaceae family comprises around 170 species of trees and bushes distributed throughout the tropical regions of America, Asia, Africa, and Australia. This family is characterized by the presence of quassinoids that are responsible for antimalarial, antiviral, insecticide, herbicidal, and antitumor activities [6]. A potent quassinoid named brusatol has been demonstrated to have antileukemic activity with an $\mathrm{IC}_{50}$ of $\sim 50 \mathrm{nM}$ [7]. In addition, recent studies have identified brusatol as a unique inhibitor of the Nrf2 pathway, which can selectively reduce the protein levels of Nrf2 via stimulated ubiquitination and proteolysis. As a result, there is interest in the therapeutic potential of brusatol as an agent for overcoming chemoresistance [8-10]. All of these reports have produced a particular interest in compounds with the quassin motif in their chemical structure.

In the Antilles, the Simaroubaceae family is represented by the genera Picrasma, Quassia, and Simarouba [11]. Simarouba tulae Urb. ("aceitillo tree") is an endemic species from of Simaroubaceae family from Puerto Rico. S. tulae is a tree reported to reach up to 60 feet in height, but overexploitation of its wood and habitat fragmentation has diminished its populations considerably [12]. Today, this species has become a rare species, with a few shrubby $8-15$ foot individuals or small trees up to 25 feet in protected forested rainy areas in Puerto Rico, including El Yunque, Carite, Susua, Maricao, and Guilarte Forests. This plant has shiny, dark green, pinnately compound leaves and terminal long-stalked clusters of dark red flowers (Figure 1).

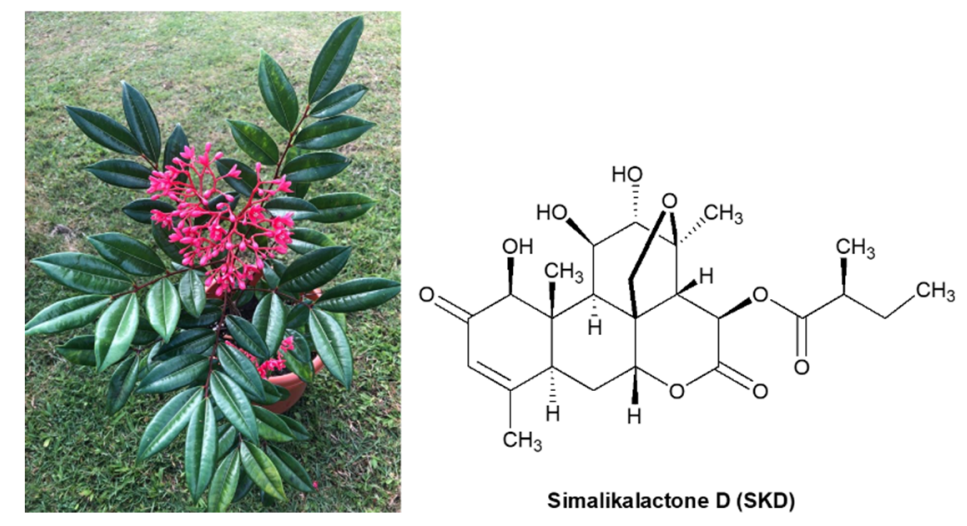

Figure 1. Picture of Simarouba tulae plant and structure of similikalactone D (SKD).

To our knowledge, no references to the chemical constituents of this species have been reported. In a preliminary study, we investigated the cytotoxic and antiproliferative activity of seven species of Puerto Rican plants, including Simarouba tulae, against three breast cancer cell lines. In this study, the crude, hexane, and chloroform extracts from Simarouba showed the highest antiproliferative activities in MCF-7 and T47D breast cancer cell lines, inhibiting more than $80 \%$ of cell proliferation at concentrations of $100 \mu \mathrm{g} / \mathrm{mL}$ [13]. In this study, leaves of this plant were used to isolate the chemical constituents responsible for its anticancer activity. Thus, this paper describes the bioassay-guided isolation, structural elucidation, revision of original structural assignments, $\mathrm{X}$-ray diffraction analysis, and cytotoxic activities of the quassinoid simalikalactone D (SKD) (Figure 1), a compound previously isolated from Simaba and Quassia species, which has been recognized to possess anticancer and antimalarial activity [14-16]. Our findings revealed that SKD has potent in vitro cytotoxicity, with $\mathrm{IC}_{50}$ values of $55 \mathrm{nM}$ in ovarian and from 58 to $67 \mathrm{nM}$ in breast cell lines, including cancer cell lines. This contribution is significant because 
we have reported the cytotoxic and antimigratory effects of SKD, a quassinoid isolated for the first time from Simarouba tulae plant.

\section{Results and Discussion}

\subsection{Assessment of the Antiproliferative Potential of Extracts in Cancer Cell Lines}

\subsubsection{Preparation of Plant Extracts}

S. tulae leaves were collected, dried, and extracted with a 1:1 mixture of dichloromethane-methanol to obtain a crude extract. The resulting crude extract was suspended in water and extracted with solvents of different polarities, including hexane, chloroform, ethyl acetate, and butanol (Table 1). The method for the preparation of the plant extracts of different polarities has been described previously and was conducted as reported [13]. According to our results, the solvents that extracted the greatest amount of metabolites were hexane and chloroform. In addition, ${ }^{1} \mathrm{H}$ and ${ }^{13} \mathrm{C}-\mathrm{NMR}$ analysis of these extracts showed the presence of signals corresponding to highly oxygenated terpenes.

Table 1. Dry Weight of Extracts from Simarouba tulae Leaves.

\begin{tabular}{cc}
\hline Extract & Dry Weight $(\mathbf{g})$ \\
\hline Crude $^{1}$ & 113 \\
Hexane & 31 \\
Chloroform & 40 \\
Ethyl acetate & 6 \\
Butanol & 15 \\
\hline
\end{tabular}

${ }^{1}$ Crude extract is composed of all chemical compounds.

\subsubsection{Determination of the Biological Activity of Plant Extracts in Cancer Cells}

Crude mixture, solvent extracts, and collected fractions of Simarouba leaves were screened for their antiproliferative activity against three malignant cancer cell lines: MDA-MB-231 (breast), A2780CP20 (cisplatin resistant ovarian), and SH-SY5Y (neuroblastoma) (Tables 2 and 3). The chloroform extract showed the highest antiproliferative effect against A2780CP20 cells at a concentrations lower than $1 \mu \mathrm{g} / \mathrm{mL}$. In addition, our NMR analysis of fractions from the chloroform extract showed that Fraction 3 contained the principal constituent of this extract, and thus demonstrated the highest inhibition at a concentration of $44 \mathrm{ng} / \mathrm{mL}$. The chloroform extract also showed antiproliferative activity against MDA-MB-231 cells at a concentration of $22 \mathrm{ng} / \mathrm{mL}$. We also evaluated the antiproliferative activity of Simarouba extract on the SH-SY5Y neuroblastoma cancer cell line at a single concentration of $3.125 \mu \mathrm{g} / \mathrm{mL}$. At this concentration, the chloroform extract, as well as Fraction 2 (SH2C2) and Fraction 3 (SH2C3), showed a percentage of growth inhibition greater than $80 \%$. These results suggest that fractions collected from the chloroform extract contained secondary metabolites with promising anticancer activity.

Table 2. Antiproliferative Effect of Simarouba Extract/Fraction on Ovarian (A2780CP20) and Breast (MDA-MB-231) Cancer Cell Lines.

\begin{tabular}{ccc}
\hline Extract/Fraction & A2780CP20 IC $_{\mathbf{5 0}}(\mu \mathrm{g} / \mathrm{mL})^{\mathbf{a}}$ & MDA-MB-231 IC $_{\mathbf{5 0}}(\mu \mathrm{g} / \mathrm{mL})^{\mathbf{a}}$ \\
\hline Crude extract & 0.75 & 2.41 \\
Hexane extract & 3.67 & 0.0024 \\
Chloroform extract & 0.14 & 0.0022 \\
Ethyl acetate extract & 36.0 & N.T. \\
Butanol extract $^{\text {SH2C3 fraction }}{ }^{\mathrm{b}}$ & 0.58 & N.T. \\
SH & 0.044 & N.T. \\
\hline
\end{tabular}

N.T.: Not tested, ${ }^{a}$ Generated using the Alamar Blue assay, ${ }^{b}$ Fraction 3 of chloroform extract. (Figures S6-S13, Supplementary Materials). 
Table 3. Antiproliferative Effect of Simarouba Extract/Fraction on Neuroblastoma SH-SY5Y Cancer Cell Line.

\begin{tabular}{|c|c|}
\hline Extract/Fraction & SH-SY5Y \%GI ${ }^{a}$ \\
\hline Crude extract & 75 \\
\hline Hexane extract & 55 \\
\hline Chloroform extract & 83 \\
\hline Ethyl acetate extract & 76 \\
\hline Butanol extract & 16 \\
\hline $\mathrm{SH} 2 \mathrm{C} 2$ fraction $\mathrm{b}$ & 80 \\
\hline $\mathrm{SH} 2 \mathrm{C} 3$ fraction $\mathrm{b}$ & 88 \\
\hline $\mathrm{SH} 2 \mathrm{C} 4$ fraction $\mathrm{b}$ & 76 \\
\hline $\mathrm{SH} 2 \mathrm{C} 5$ fraction $\mathrm{b}$ & 64 \\
\hline
\end{tabular}

a \%GI = percentage of growth inhibition, generated using the sulforhodamine $\mathrm{B}$ assay. All extracts were tested at a single dose of $3.125 \mu \mathrm{g} / \mathrm{mL},{ }^{\text {b }}$ Fractions 2 to 5 (SH2C2 to SH2C5) are from chloroform extract.

\subsection{Purification, Isolation, and Characterization of Simalikalactone D (SKD)}

The chloroform extract (40 g) of Simarouba tulae was chromatographed on Si gel with 5\% methanol in chloroform to obtain seven fractions (1-7). Fraction $3(1.1 \mathrm{~g})$ was purified on a sephadex LH-20 column to give six fractions (A-F). Subfraction C $(730 \mathrm{mg})$ was purified successively by column chromatography with a mixture of chloroform/methanol (97:3), and finally by reversed phase HPLC (Figure 2) with a mixture of $45 \%$ methanol in water to afford $8 \mathrm{mg}$ of a pure compound which was identified as the known quassinoid simalikalactone $\mathrm{D}$ (SKD). In order to obtain greater quantities of SKD, we optimized the purification method. SKD was purified by normal phase column chromatography on silica gel diol using a mixture of chloroform/methanol (97:3) from subfraction D and Fraction 2. Through this purification method, we isolated $150 \mathrm{mg}$ of SKD. The structure of SKD was elucidated by spectroscopic methods and further confirmed by X-ray diffraction. The ${ }^{1} \mathrm{H}-{ }^{1} \mathrm{H}$ COSY, HMQC, and HMBC experiments revealed the presence of four spin systems (A-D) (Figure 3). The spin systems' connectivity was established unambiguously by HMBC experiment. Systems A and B were confidently linked by the $\mathrm{HMBC}$ correlation between $\mathrm{C}-5$ and $\mathrm{H}_{3}-19$, whereas systems $\mathrm{A}$ and $\mathrm{C}$ were connected by the key HMBC correlation between C-9 and H-1. In addition, the HMBC correlation for C-8/H-6b and C-7/H-20a linked systems B and C. Finally, HMBC cross-peaks between C-22 and H-14 allowed the attachment of systems $C$ and D, thus completing the planar structure of SKD. However, our spectroscopic data analysis revealed seven NMR assignments in $\mathrm{CDCl}_{3}$ (deuterated chloroform) that were not in accordance with the structure reported in 1993 (Table 4) [14]. Critically, the ${ }^{13}$ C-NMR assignments for quaternary carbons $\mathrm{C}-8$ and $\mathrm{C}-10$ should have been exchanged, as originally reported from HMBC correlations for $\mathrm{C}-8 / \mathrm{H}-20 \mathrm{~b}$ and $\mathrm{C}-10 / \mathrm{H}-1 / \mathrm{H}_{3}-19$. The same situation of exchange should have been presented for the ${ }^{13} \mathrm{C}-\mathrm{NMR}$ assignments for carbons $\mathrm{C}-11$ and $\mathrm{C}-12$ from HMBC correlations for C-8/H-11, C-14/H-12, and C-21/H-12. The ${ }^{13} \mathrm{C}-\mathrm{NMR}$ assignments for methyl groups 19, 21, and 24 should have been revised as originally reported from HMQC correlations with their protons at $\delta_{\mathrm{H}}$ $1.19,1.44$, and 1.21, respectively. Further analysis of HMBC correlations for C-19 at $\delta_{\mathrm{C}} 11.4$ and $\mathrm{H}-1$, $\mathrm{C}-21$ at $\delta_{\mathrm{C}} 22.9$ and $\mathrm{H}-12$, and $\mathrm{C}-24$ at $\delta_{\mathrm{C}} 16.6$ and $\mathrm{H}-23$, unambiguously established the ${ }^{13} \mathrm{C}-\mathrm{NMR}$ assignments for C-19, C-21, and C-24. Moreover, the proposed assignments revisions were similar to the assignments reported for other quassinoids isolated from the Simaroubacea family, such as simalikalactone E (SKE) and orinocinolide (Table 4) and to those gathered in a literature review [15-18]. Thus, the earlier reported NMR assignments for SKD were deemed to be incorrectly positioned, and their $\delta_{C}$ was revised as shown in the Materials and Methods section. The relative stereochemistry for the twelve chiral centers in the pentacyclic framework of SKD was established by analysis of NOESY experiment and was similar to the original reported structure [14]. The correlations of $\mathrm{H}-1 / \mathrm{H}-5, \mathrm{H}-1 / \mathrm{H}-9$, $\mathrm{H}-9 / \mathrm{H}-11$, and $\mathrm{H}-9 / \mathrm{H}-15$ suggested that these hydrogens were in $\alpha$-face. On the other hand, correlations between $\mathrm{H}-14 / \mathrm{H}-7, \mathrm{Me}-19 / \mathrm{H}-20 \mathrm{~b}$, and $\mathrm{H}-12 / \mathrm{H}-20 \mathrm{~b}$ revealed that these hydrogens were in the $\beta$-face. Fortunately, single-crystal $\mathrm{X}$-ray diffraction analysis revealed the stereochemical rearrangements of the 
12 chiral centers in SKD through the determination of its relative configuration, as confirmed by NMR experiments (Figure 4).

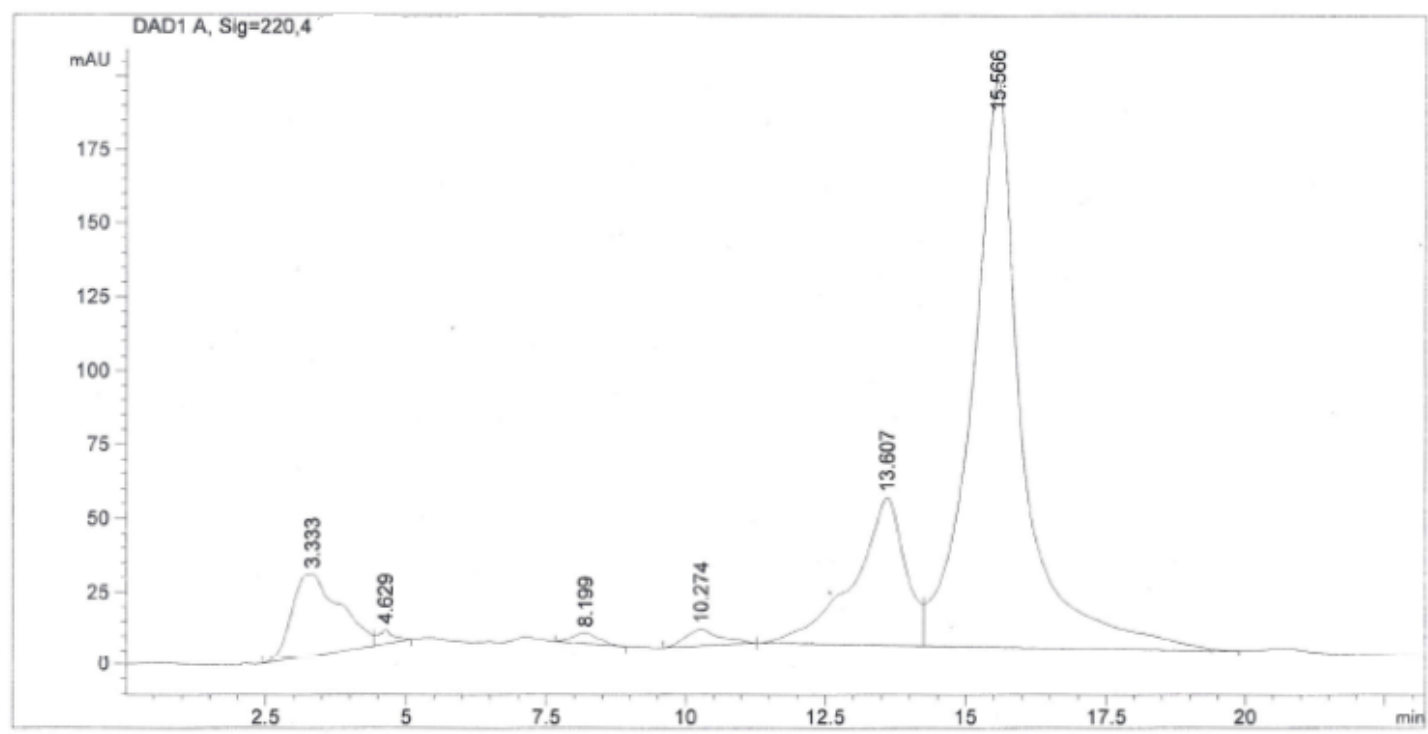

Figure 2. HPLC chromatogram of Fraction 3 (SH2C3) containing simalikalactone D (SKD). SH2C3 fraction was purified on a C18 column with a mixture of methanol and water $(55: 45, \mathrm{v} / \mathrm{v})$ as a mobile phase, at flow rate of $0.65 \mathrm{~mL} / \mathrm{min}$ and with UV detection at $220 \mathrm{~nm}$. SKD was collected separately in the interval of $15.57 \mathrm{~min}$.

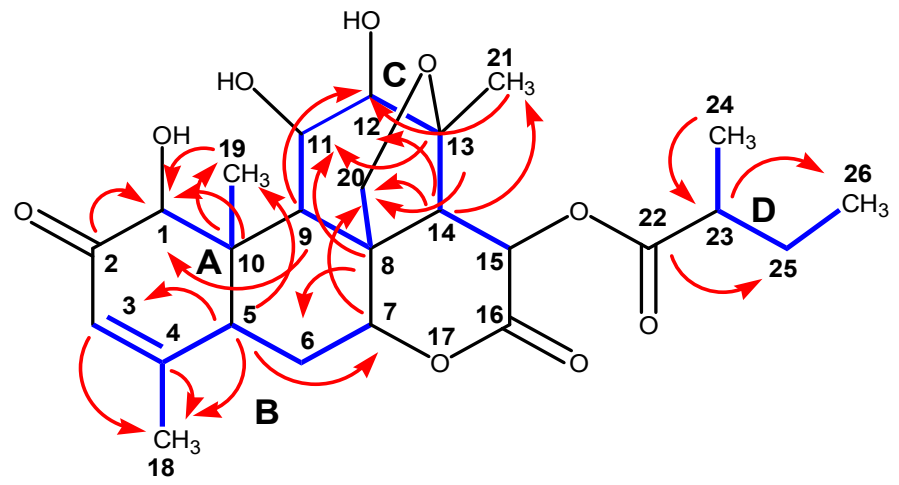

COSY and HMQC correlations

HMBC correlations: $\mathrm{C} \longrightarrow \mathrm{H}$

Figure 3. Partial structures for simalikalactone D (SKD) generated from COSY, HMQC, and HMBC experiments.

Table 4. Selected ${ }^{1} \mathrm{H}$ NMR and ${ }^{13} \mathrm{C}$ NMR Spectral Data for Reported and Revised Simalikalactone D (SKD), Simalikalactone E (SKE), and Orinocinolide.

\begin{tabular}{ccccc}
\hline Atom $^{\mathbf{a}}$ & Reported SKD $^{\mathbf{b}} \boldsymbol{\delta}_{\mathbf{H}}, \delta_{\mathbf{C}}$ & Revised SKD ${ }^{\mathbf{c}} \boldsymbol{\delta}_{\mathbf{H}}, \delta_{\mathbf{C}}$ & $\mathbf{S K E}^{\mathbf{d}} \delta_{\mathbf{H}}, \delta_{\mathbf{C}}$ & Orinocinolide $^{\mathbf{d}} \delta_{\mathbf{H}}, \delta_{\mathbf{C}}$ \\
\hline $8^{\mathrm{e}}$ & 47.7 & 45.9 & 46.1 & 44.1 \\
$10^{\mathrm{e}}$ & 45.9 & 47.7 & 50.4 & 46.5 \\
11 & $3.77,79.4$ & $4.64,74.4$ & $4.75,74.2$ & $4.70,74.8$ \\
12 & $4.63,74.4$ & $3.79,79.4$ & $3.83,79.8$ & $3.66,78.9$ \\
19 & $1.18,22.9$ & $1.19,11.4$ & $1.35,12.5$ & $1.20,12.0$ \\
21 & $1.43,16.6$ & $1.44,22.9$ & $1.45,22.8$ & $1.39,23.4$ \\
24 & $1.22,11.4$ & $1.21,16.6$ & $1.21,16.7$ & $1.18,16.7$ \\
\hline
\end{tabular}

All spectra were recorded in $\mathrm{CDCl}_{3}$, a The carbon numbering system is in accordance with the numbering of the quassolidane skeleton and the original structure reported for SKD, b ${ }^{1} \mathrm{H}-\mathrm{NMR}(300 \mathrm{MHz})$ and ${ }^{13} \mathrm{C}-\mathrm{NMR}(75 \mathrm{MHz})$, ${ }^{\mathrm{c}}{ }^{1} \mathrm{H}-\mathrm{NMR}(400 \mathrm{MHz})$, and ${ }^{13} \mathrm{C}-\mathrm{NMR}(100 \mathrm{MHz}),{ }^{11} \mathrm{H}-\mathrm{NMR}(500 \mathrm{MHz})$, and ${ }^{13} \mathrm{C}-\mathrm{NMR}(125 \mathrm{MHz}),{ }^{\mathrm{e}}$ Only $\delta_{\mathrm{C}}$ are reported as $\mathrm{C}-8$ and $\mathrm{C}-10$ are quaternary carbons. 


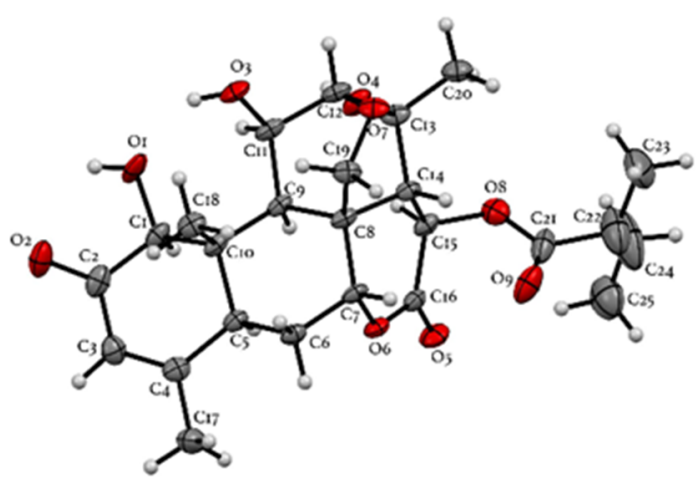

(a)

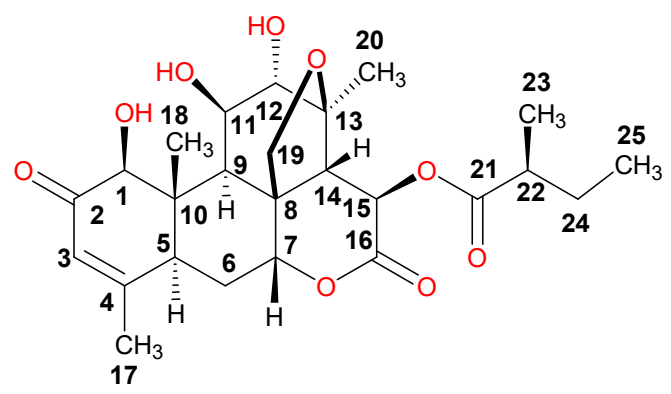

(b)

Figure 4. (a) Illustration of the crystal structure of SKD with thermal ellipsoids drawn at 50\% probability; (b) structure of SKD showing all the chiral centers. To facilitate analysis, the carbon numbering system for Positions 17 to 25 are the same as those generated for the $\mathrm{X}$-ray structure (Figure S27, Supplementary Materials).

\subsection{Potential Antiproliferative Activity of Simalikalactone D (SKD)}

Most scientific studies on SKD have concentrated on developing SKD as an antimalarial agent $[16,19,20]$. However, there have been some in vitro studies regarding its cytotoxic activities at low concentrations (1.0 to $0.2 \mu \mathrm{M})$ in cancer cell lines such as KB (human epidermal carcinoma), P-388 (lymphocytic leukemia), BT-549 (human ductal carcinoma), MCF-7 (breast), SK-OV-3 (ovarian), and Vero cells $[14,16,17,21,22]$. In this study, we decided to expand the cytotoxic potential of SKD by evaluating its activity in aggressive cancer cell lines associated with a poor prognosis, resistance, and difficult treatment. Therefore, SKD was evaluated for its growth inhibitory potency against several cancer cell lines including A2780CP20 (cisplatin resistant ovarian), MDA-MB-231 (breast), MDA-MB-435 (breast), 4T1 (breast), PC3 (prostate), HCT-116 (colon), and SH-SY5Y (neuroblastoma). As shown in Table 5, SKD showed potent in vitro cytotoxicity, with an $\mathrm{IC}_{50}$ of $55 \mathrm{nM}$ against $\mathrm{A} 2780 \mathrm{CP} 20$ ovarian cancer cells. In the highly metastatic MDA-MB-231 and MDA-MB-435 cancer cell lines, SKD inhibited cell viability with an $\mathrm{IC}_{50}$ of 65 and $58 \mathrm{nM}$, respectively. However, SKD demonstrated a similar $67 \mathrm{nM} \mathrm{IC}_{50}$ in the MCF10A non-cancer mammary epithelial cell line, indicating potential toxic effects in normal breast cells. Additionally, SKD inhibited growth proliferation of the highly aggressive 4T1 mouse mammary tumor cell line with an $\mathrm{IC}_{50}$ above $100 \mathrm{nM}\left(\mathrm{IC}_{50}=218 \mathrm{nM}\right)$. Similarly, in the PC3 prostate cancer, HCT-116 colon cancer, and SH-SY5Y neuroblastoma cell lines, SKD inhibited cell viability with an $\mathrm{IC}_{50}$ above $100 \mathrm{nM}$. Future studies will confirm the cytotoxic potential of SKD in a range of non-cancer cell lines prior to the translational development of SKD for breast and ovarian cancer.

Table 5. Antiproliferative Effect of SKD on Cell Lines.

\begin{tabular}{cc}
\hline Cell Line & IC $_{50}(\mathbf{n M})^{\mathrm{a}}$ \\
\hline A2780CP20 (Ovarian cancer) ${ }^{\mathrm{c}}$ & $55^{\mathrm{a}}$ \\
MDA-MB-231 (Breast cancer) $^{\mathrm{d}, \mathrm{g}}$ & $65^{\mathrm{a}}, 63^{\mathrm{b}}$ \\
MDA-MB-435 (Breast cancer) $^{\mathrm{d}}$ & $58^{\mathrm{b}}$ \\
4T1 (Breast cancer) & $>100^{\mathrm{b}}$ \\
MCF10A (Breast epithelial cells) & $67^{\mathrm{f}}$ \\
PC3 (Prostate cancer) & $>100^{\mathrm{a}}$ \\
HCT-116 (Colon cancer) & $>100^{\mathrm{a}}$ \\
SH-SY5Y (Neuroblastoma) & $>100(39.8 \mu \mathrm{M})^{\mathrm{b}}$
\end{tabular}

${ }^{a}$ Generated using the Alamar Blue assay, ${ }^{\mathrm{b}}$ Generated using the sulforhodamine B assay, ${ }^{\mathrm{c}}$ cisplatin-resistant ovarian cancer, ${ }^{d}$ metastatic mammary adenocarcinoma, ${ }^{\mathrm{e}}$ mouse metastatic mammary carcinoma. ${ }^{\mathrm{f}}$ Generated using the MTT assay, ${ }^{8}$ IC $_{50}$ of Brusatol using MTT was 390 nM [8] (Figures S14-S26, Supplementary Materials). 
We also evaluated the long-term effects of SKD on cell proliferation in cisplatin-resistant ovarian cancer (A2780CP20) cells by performing colony formation assays. Representative Petri dishes for the number of colonies in untreated cells and cells treated with SKD are shown in Figure 5a. Figure 5b shows that SKD significantly reduced the number of colonies compared with untreated cells. Even concentrations as low as $25 \mathrm{nM}$ significantly reduced the number of colonies compared to the DMSO used as a control (Figure $5 b$ ). Together, these results indicate that SKD exerts short-term (reduction of cell viability) and long-term effects (colony formation assays) on the growth and proliferation of cancer cells.
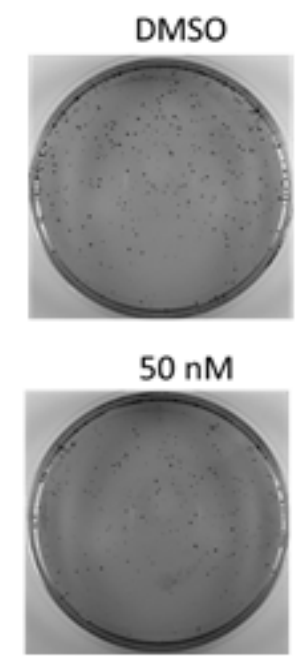

(a)
$25 \mathrm{nM}$

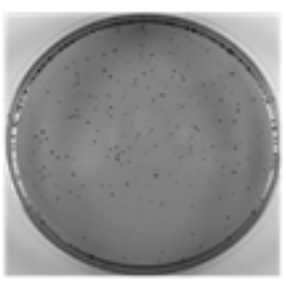

$100 \mathrm{nM}$

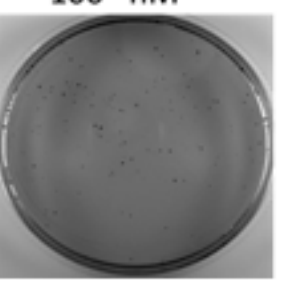

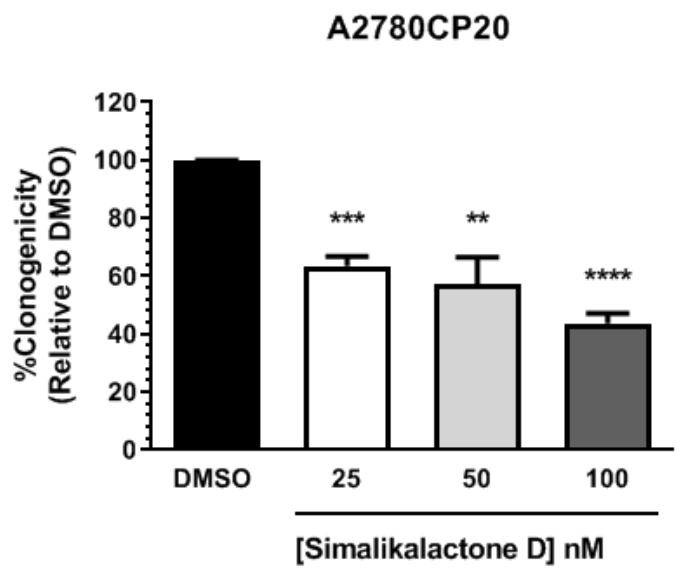

(b)

Figure 5. Anti-proliferative effect of SKD in cisplatin-resistant ovarian cancer cells, A2780CP20. Cells were treated with vehicle (DMSO) or SKD. After $24 \mathrm{~h}$, a colony formation assay was performed as described in the Materials and Methods section. (a) Representative images of colonies grown in Petri dishes. (b) Graph shows that SKD significantly reduced the number of colonies compared with control cultures (100\%). Experiments were performed in triplicate. ${ }^{* * *} p<0.0001,{ }^{* * *} p<0.001,{ }^{* *} p<0.01$.

\subsection{Anti-Migratory Activity of Simalikalactone D (SKD)}

The major cause of death in breast cancer patients is the metastasis of primary tumor cells to secondary tissues. To successfully invade a secondary site, a cancer cell completes a series of steps including migration from the primary tumor, invasion of surrounding tissues and basemen membranes, intravasation and survival during circulation, and arrest at a distant target organ [23]. In recent years, many natural products, including compounds from medicinal plants, have been shown to have effective activities against tumor invasion and metastasis [24,25]. The cytotoxic activity of compound SKD on the MDA-MB-231 cell line was determined to be potent, with an $\mathrm{IC}_{50}$ of $63 \mathrm{nM}$ using the sulforhodamine B (SRB) assay [26] (Table 5). However, to our knowledge, the anti-migratory activity of SKD remains unexplored. To further assess the anti-migratory activity of SKD in vitro, we examined its inhibitory effects on migration of the metastatic breast cancer cell line MDA-MB-231, chosen due to its enhanced metastatic and migratory properties. The anti-migratory activity was determined using the wound healing assay (scratch assay) [27]. In this assay, the relative migration of MDA-MB-231 cancer cells in the presence of SKD at a concentration of $32 \mathrm{nM}$ (a concentration that did not affect cell viability) was compared to vehicle $(0.02 \%$ DMSO). Representative micrographs of the migration inhibition of compound SKD are represented in Figure 6. Results show that in the vehicle-treated control experiment, wound healing progressed considerably, and after $24 \mathrm{~h}$, the wound was completely healed. On the other hand, when cells were incubated with SKD after $24 \mathrm{~h}$, wound healing was inhibited by $15 \%$. This low inhibition rate for migration may have been due to our selection of a 
concentration of SKD that was $50 \%$ below the $\mathrm{IC}_{50}$ of $65 \mathrm{nM}$ for cell viability inhibition, to avoid confounding effects on cell viability inhibition.
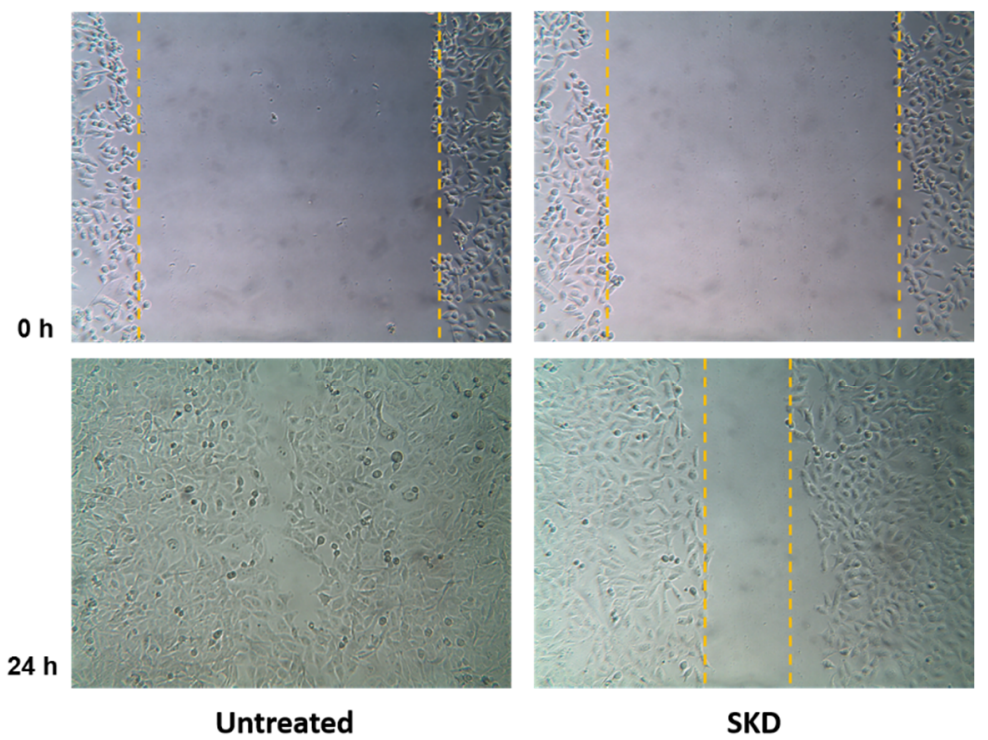

Figure 6. Inhibitory effect of SKD on MDA-MB-231 cell migration detected by a wound-healing assay. MDA-MB-231 were treated with vehicle or with SKD compound. Representative photomicrographs were obtained at 0 and $24 \mathrm{~h}$. Percent relative migration values are the average of three independent experiments. Dotted lines show the area occupied by the initial scraping for $0 \mathrm{~h}$, and the wound edge after $24 \mathrm{~h}$.

We will continue with the elucidation and characterization of the molecular mechanisms of SKD in breast and ovarian cancer cell lines, as well as in non-cancer epithelial cells. Potential toxicity in non-cancer cells will be addressed by testing SKD delivery in targeted nanocarriers. We will also improve selectivity by the preparation and isolation of simalikalactone $\mathrm{D}$ derivatives.

\section{Materials and Methods}

\subsection{General Experimental Procedures}

All reagents and solvents, including dichloromethane, chloroform, methanol, hexane, ethyl acetate, and butanol, were purchased from Sigma Aldrich. The plant extracts were concentrated using a Buchi Rotavapor R-300. Column chromatography was performed using silica gel (35-75 mesh and 200-425 mesh), diol silica gel (75-200 mesh), silica gel C-18 reversed-phase (35-75 mesh), and sephadex LH-20. TLC analyses were carried out using Analtech glass precoated Si gel plates and precoated reversed-phase Si gel plates. Spots were detected on TLC under UV light or iodine vapors chamber. IR spectra were recorded on a Jasco FT/IR 4200 spectrometer. HPLC was performed on a Perkin Elmer Series 200 instrument equiped with a Kromasil C-18 Column $(250 \times 4.6 \mathrm{~mm}, 5 \mu \mathrm{m}$, flow rate: $1 \mathrm{~mL} / \mathrm{min})$. NMR data were recorded on a Bruker NMR spectrometer operating at $400 \mathrm{MHz}$ for ${ }^{1} \mathrm{H}-\mathrm{NMR}$ and $100 \mathrm{MHz}$ for ${ }^{13} \mathrm{C}$-NMR. All ${ }^{1} \mathrm{H}-\mathrm{NMR}$ and ${ }^{13} \mathrm{C}$-NMR chemical shifts were referenced to residual $\mathrm{CHCl}_{3}$ in the deuterated solvent (7.26 ppm for ${ }^{1} \mathrm{H}-\mathrm{NMR}$ and $77.0 \mathrm{ppm}$ for $\left.{ }^{13} \mathrm{C}-\mathrm{NMR}\right)$.

\subsection{Plant Material}

Fresh leaves from healthy young adult trees growing in open secondary forest were collected from the Carite State Forest, near the Charco Azul natural swimming pool at Patillas Puerto Rico. The plant species was identified and deposited in the Herbarium at the University of Puerto Rico, Rio Piedras Campus. According to the Holdridge classification system, this is an area of subtropical moist forest, approximately $610 \mathrm{~m}$ above sea level (masl) with an annual precipitation of 88.7 inches and annual 
temperature of $72.3^{\circ}$ F. Soils are well-drained, very deep, clayey soils in the Los Guineos Series [28,29]. Additionally, we obtained vegetative material for $S$. tulae from nursery-grown trees from Reforesta, Inc. San Juan, Puerto Rico.

\subsection{Spectroscopic Data of Simalikalactone D (SKD)}

\subsubsection{Simalikalactone D (SKD)}

White solid; m.p. $228-231^{\circ} \mathrm{C}$; IR (NaCl) $v_{\max } 3442,3100,2932,1744,1666,1431,1379,1342,1207$, $1145,1067,1036,864,817 \mathrm{~cm}^{-1}$; TLC analysis in $\mathrm{CHCl}_{3} / \mathrm{MeOH}(9.7 / 0.3), \mathrm{R}_{\mathrm{f}}=0.37 .{ }^{1} \mathrm{H}-\mathrm{NMR}\left(\mathrm{CDCl}_{3}\right.$, $400 \mathrm{MHz}$ ) $\delta 6.11$ (brs, 1H, H-15), 6.10 (s, 1H, H-3), 4.68 (brs, 1H, H-7), 4.64 (brs, 1H, H-11), 4.63 (d, $J=7.6 \mathrm{~Hz}, 1 \mathrm{H}, \mathrm{H}-20 \mathrm{~b}), 4.16$ (s, 1H, H-1), 3.79 (s, 1H, H-12), 3.54 (d, J = $7.6 \mathrm{~Hz}, 1 \mathrm{H}, \mathrm{H}-20 \mathrm{a}), 2.94$ (1H, brd, $J=12.8 \mathrm{~Hz}, 1 \mathrm{H}, \mathrm{H}-5), 2.45$ (m, 1H, H-23), 2.43 (m, 1H, H-14), 2.38 (dt, J = 14.5, $2.8 \mathrm{~Hz}, 1 \mathrm{H}, \mathrm{H}-6 \mathrm{~b}), 2.31$ (brs, 1H, H-9), 1.96 (s, 3H, H-18), 1.80 (m, 1H, H6a), 1.75 (m, 1H, H-25b), 1.51 (m, 1H, H-25a), 1.44 (s, $3 \mathrm{H}, \mathrm{H}-21), 1.21$ (d, J = 7.0 Hz, 3H, H-24), 1.19 (s, 3H, H-19), 0.98 (t, J = 7.6 Hz, 3H, H-26); ${ }^{13} \mathrm{C}-\mathrm{NMR}$ $\left(\mathrm{CDCl}_{3}, 100 \mathrm{MHz}\right) \delta 197.2$ (C, C-2), 175.4 (C, C-22), 167.7 (C, C-16), 163.5 (C, C-4), 124.2 (CH, C-3), 83.1 (CH, C-7), $81.7(\mathrm{CH}, \mathrm{C}-1), 80.4(\mathrm{C}, \mathrm{C}-13), 79.4(\mathrm{CH}, \mathrm{C}-12), 74.4(\mathrm{CH}, \mathrm{C}-11), 71.7\left(\mathrm{CH}_{2}, \mathrm{C}-20\right), 67.3(\mathrm{CH}$, C-15), 52.4 (CH, C-14), 47.7 (C, C-10), 45.9 (C, C-8), 43.5 (CH, C-5), 42.5 (CH, C-9), 41.1 (CH, C-23), 28.3 $\left(\mathrm{CH}_{2}, \mathrm{C}-6\right), 26.5\left(\mathrm{CH}_{2}, \mathrm{C}-25\right), 22.9\left(\mathrm{CH}_{3}, \mathrm{C}-21\right), 22.6\left(\mathrm{CH}_{3}, \mathrm{C}-18\right), 16.6\left(\mathrm{CH}_{3}, \mathrm{C}-24\right), 11.6\left(\mathrm{CH}_{3}, \mathrm{C}-26\right), 11.4$ $\left(\mathrm{CH}_{3}, \mathrm{C}-19\right)$ (Figures S1-S5, Supplementary Materials).

\subsubsection{Crystal Data for Simalikalactone D (SKD)}

SKD was crystallized by slow evaporation of ethyl acetate. X-ray diffraction data were obtained from single crystals mounted on a loop. The data were collected on a Rigaku SuperNova, single-source HyPix3000 diffractometer with $\mathrm{Cu} \mathrm{K} \alpha$ radiation $(\lambda=1.5406 \AA)$ at 100.01(10) K. Data reduction was performed using the program CrysAlis ${ }^{\text {Pro }}$. No absorption correction was performed. The structures were resolved through direct method and refined by full-matrix least-square methods on $\mathrm{F}^{2}$. All non-hydrogen atoms were refined anisotropically, while $\mathrm{H}$ atoms were placed in calculated position with their thermal parameters riding in those of their C atoms (Figure S27, Supplementary Materials).

\subsection{Biological Evaluation}

\subsubsection{Cell Lines and Culture Conditions}

MDA-MB-231, PC3, HCT-116, 4T1, and MCF-10A cells were purcharsed from The American Type of Culture Collection (ATCC). A2780CP20 cells were provided by Dr. Anil K. Sood (MD Anderson Cancer Center). MDA-MB-435 cells were provided by Dr. Suranganie Dharmawardhane (University of Puerto Rico, Medical Sciences) and characterized in Reference [30], from Dr. Danny R. Welch, The University of Kansas Cancer Center, Kansas City, KS. Cells were routinely grown and maintained in RPMI-1640 medium with 10\% FBS and with 1\% antibiotic/antimicotic solution in a humidified incubator containing $95 \%$ air and $5 \% \mathrm{CO}_{2}$.

\subsubsection{Cell Viability and Colony Formation Assays}

Cells $\left(3 \times 10^{4}\right.$ cells $\left./ \mathrm{mL}\right)$ were plated in 96 well plates and, $24 \mathrm{~h}$ later, serial dilutions $(1.0-0.1 \mathrm{mg} / \mathrm{mL})$ of each plant extract in DMSO were added to the cells in triplicate. Blank (medium without cells), experimental (cells following treatment in plant extract), vehicle control ( $0.1 \%$ DMSO in medium), and positive control (cisplatin) groups were included in each experiment. Seventy-two hours after treatment, the medium was removed and Alamar blue dye (Thermo Fisher Scientific) was added following the manufacturer's instructions. Optical density (OD) values were obtained using a plate reader (Bio-Rad) and percentages of cell viability were calculated after blank OD subtraction, taking the untreated cell values as $100 \%$ cell viability. For assessment of cell proliferation, colony formation assays were performed using Crystal violet dye (Sigma). Briefly, A2780CP20 cells $\left(3 \times 10^{4}\right.$ cells $\left./ \mathrm{mL}\right)$ 
were seeded into six well plates. Twenty-four hours later, simalikalactone D (SKD) (100, 50, and 25 nM) was added to the cells. The next day, 1000 cells were seeded into $10 \mathrm{~cm}$ Petri dishes. Ten days later, colonies were fixed and stained with $0.5 \%$ crystal violet solution in methanol. Colonies of at least 50 cells were scored in five random fields using a light microscope (Olympus CKX41) with a total magnification of $40 \times$. Graphs, statistical analysis, and $\mathrm{IC}_{50}$ calculations were done using GraphPad Prism (San Diego, CA, USA).

\subsubsection{MTT (3-(4,5-Dymethyl thiazol-2-yl)-2,5-diphenyl Tetrazolium Bromide) Assay for Cell Viability}

Promega-CellTiter $96{ }^{\circledR}$ Non-Radioactive Cell Proliferation Assay was performed as per manufacturer's instructions. Briefly, MCF10A cells were seeded in a 24 well plate and treated for $72 \mathrm{~h}$ with a range of SKD concentrations at 0, $16.25 \mathrm{nM}, 32.5 \mathrm{nM}, 65 \mathrm{nM}, 130 \mathrm{nM}$, and $260 \mathrm{nM}$ in culture medium. After incubation, the MTT reagent was added to the plate $(40 \mu \mathrm{L} /$ well $)$. The plates were incubated for $4 \mathrm{~h}$ at $37^{\circ} \mathrm{C}$, stop solution was added to each well, and the plates were incubated to facilitate solubilization of formed formazan salts. The absorbance was measured at $570 \mathrm{~nm}$ using a microplate reader. $\mathrm{IC}_{50}$ was calculated from sigmoidal dose-response curves using GraphPad Prism V. 6.02, GraphPad Software, Inc. (San Diego, CA, USA).

\subsubsection{Sulforhodamine B (SRB) Assay}

A stock solution of simalikalactone D(SKD) was prepared at $50 \mathrm{mM}$ in $100 \%$ DMSO. For preparation of cells, a flask of $75 \mathrm{~cm}^{2}$ or $25 \mathrm{~cm}^{2}$ containing $2.6 \times 10^{5}$ cells $/ \mathrm{mL}$ or $1.44 \times 10^{5}$ cells $/ \mathrm{mL}$ at $80 \%-90 \%$ confluence was used. Cells were washed with PBS and trypsinized. The concentration of cells was determined from a 1:2 dilution with Trypan Blue, using a hemocytometer. After cells were counted, the concentration was adjusted to 7.0-10.0 × 10 4 cells/mL. Approximately $100 \mu \mathrm{L}$ of cell suspension, SKD, and positive and negative controls were added in triplicate to a 96 well plate. Positive control was doxorubicin, and the negative control was DMSO 0.1\%. All compounds at concentrations of 50, 25, $12.5,6.3,1.6,0.8,0.4,0.2,0.1,0.05$, and $0.02 \mu \mathrm{M}$ were incubated with cells at $37^{\circ} \mathrm{C}$ for $48 \mathrm{~h}$. For fixation, cold TCA $50 \%$ was used and incubated at $4{ }^{\circ} \mathrm{C}$ for $1 \mathrm{~h}$. Wells were washed and dried prior to tincture with $100 \mu \mathrm{L}$ of SRB $0.4 \%$. To remove excess SRB, acetic acid was used. For analysis, TRIS-BASE solution ( $\mathrm{pH}=10.5$ ) was used, and shaken prior to quantification using an ELISA reader at $540 \mathrm{~nm}$ and SoftMax Pro 4.8 software. For compound SKD, $\mathrm{IC}_{50}$ was calculated from sigmoidal dose-response curves (variable-slope) which were generated with data obtained from experiments carried out in triplicate ( $\mathrm{IC}_{50}$ values were generated with GraphPad Prism V. 6.02, GraphPad Software, Inc.).

\subsubsection{Wound Healing Assay (Scratch Assay) Using MDA-MB-231 Cancer Cell Line}

Prior to assays, cells were grown to $80 \%-90 \%$ confluence. The cells were washed with PBS to remove all traces of FBS. Cells were detached by incubation in trypsin for $5-10 \mathrm{~min}$ at $37^{\circ} \mathrm{C}$. At the end of the incubation time, cells were re-suspended and counted with hemocytometer at a 1:2 dilution with Trypan blue. Subsequently, cell viability was calculated. In a 12 multiwell plate, cells were seeded at $1.5-2.2 \times 10^{5}$ cells $/ \mathrm{mL}$ in $1 \mathrm{~mL}$ and incubated for $24 \mathrm{~h}$. Cells were then rinsed with PBS and incubated in starving media $(0.5 \%$ FBS) overnight. The compound SKD was tested in triplicate. The negative control for each drug was prepared according to the drug's DMSO concentration. SKD was diluted and the final concentration in each well was $0.032 \mu \mathrm{M}$ (or $\mathrm{IC}_{50} / 2$ on MDA-MB-231 cells). The wound was made using a sterile $200 \mu \mathrm{L}$ pipette tip. After $24 \mathrm{~h}$ incubation, the gap distance was evaluated using Lumera Infinity Analyze 6.4.0 software. Pictures were taken at 0,8,12, and $24 \mathrm{~h}$ using a $10 \times$ objective in an Inverted Laboratory Microscope Leica DM IL LED, and an Infinity1-3 3.1 Megapixel USB 2.0 camera CMOS. The percentage of migration was calculated using the following formulae:

$$
\begin{gathered}
100-\left[\left(\mathrm{X}_{0} / \ddot{\mathrm{X}}_{0}\right)\right] \times 100 \text { for time } 0 \mathrm{~h} \text { measurements } \\
100-\left[\left(\mathrm{X}_{24} / \ddot{\mathrm{X}}_{0}\right)\right] \times 100 \text { for time } 24 \mathrm{~h} \text { measurements }
\end{gathered}
$$




\section{Conclusions}

In this study, we characterized the quassinoid Simalikalactone D (SKD), a metabolite isolated from the Puerto Rican endemic plant Simarouba tulae. SKD showed strong cytotoxic activity at nanomolar concentrations against MDA-MB-231 breast, MDA-MB-435 breast, and A2780CP20 ovarian cancer cells. In addition, SKD had antiproliferative effects, as observed from colony formation assays. Moreover, SKD exhibited a migration inhibition of $15 \%$ in the metastatic breast cancer line MDA-MB-231. Although SKD inhibited the viability of MDA-MB-231 breast cancer cells, it showed a similar cytotoxic effect on MCF10A mammary epithelial cells. Therefore, future studies will need to determine the usefulness of SKD in adjuvant chemotherapy by delivering SKD in a targeted delivery system to cancer cells. Finally, studies of the mechanism of action focused on the effect of SKD in apoptotic pathways, target identification, and in vivo studies are needed to fully characterize and analyze the potential of this natural product as an anticancer compound.

Supplementary Materials: The following are available online at http://www.mdpi.com/2223-7747/9/1/93/s1, Figure S1: ${ }^{1} \mathrm{H}-\mathrm{NMR}$ Spectrum $(400 \mathrm{MHz})$ of Simalikalactone D (SKD) in $\mathrm{CDCl}_{3}$, Figure S2: ${ }^{13} \mathrm{C}-\mathrm{NMR}$ Spectrum $(100 \mathrm{MHz})$ of Simalikalactone D (SKD) in $\mathrm{CDCl}_{3}$, Figure S3: 2D HMQC NMR Spectrum of Simalikalactone D (SKD) in $\mathrm{CDCl}_{3}$, Figure S4: 2D COSY NMR Spectrum of Simalikalactone D (SKD) in $\mathrm{CDCl}_{3}$, Figure S5: 2D HMBC NMR Spectrum of Simalikalactone D (SKD) in $\mathrm{CDCl}_{3}$, Figure S6: Antiproliferative Effect of Simarouba Extract/Fraction on A2780CP20 (Ovarian). Figure S7: Antiproliferative Effect of Simarouba Hexane Extract/Fraction on A2780CP20 (Ovarian). Figure S8: Antiproliferative Effect of Simarouba Chloroform Extract/Fraction on A2780CP20 (Ovarian). Figure S9: Antiproliferative Effect of Simarouba Ethyl Acetate Extract/Fraction on A2780CP20 (Ovarian). Figure S10: Antiproliferative Effect of Simarouba Butanol Extract/Fraction on A2780CP20 (Ovarian). Figure S11: Antiproliferative Effect of Simarouba SH2C3 Fraction on A2780CP20 (Ovarian). Figure S12: Antiproliferative Effect of Simarouba Crude Extract on MDA-MB-231 cells. Figure S13: Antiproliferative Effect of Simarouba Chloroform Extract on MDA-MB-231 cells. Figure S14: Antiproliferative Effect of SKD on MCF10A cells. Figure S15: Antiproliferative Effect of SKD on MDA-MB-231 cells. Figure S16: Antiproliferative Effect of SKD on SHSY5Y neuroblastoma cells. Figure S17: Antiproliferative Effect of SKD on MDA-MB-435 cells. Figure S18: Antiproliferative Effect of SKD on $4 \mathrm{~T} 1$ cells. Figure S19: Antiproliferative Effect of SKD on A278CP20 cells. Figure S20: Dose-response data obtained from cell viability of SKD on MCF1A cells. Figure S21: Dose-response data obtained from cell viability of SKD on MDA-MB-231 cells. Figure S22: Dose-response data obtained from cell viability of SKD on SH-SY5Y cells. Figure S23: Dose-response data obtained from cell viability of SKD on MDA-MB-435 cells. Figure S24: Dose-response data obtained from cell viability of SKD on 4T1 cells. Figure S25: Dose-response data obtained from cell viability of SKD on A278CP20 cells. Figure S26: Dose-response data obtained from cell viability of SKD on HCT-116 cells. Figure S27: Illustration of the crystal structure of SKD with H-bond interactions and crystal packing of SKD observed along the $b$ axis. Supporting information regarding the crystal structure in this article can be found in the online version of the journal. Crystallographic information files for SKD is available from the Cambridge Crystallographic Data Center, CCDC 1947777. These data can be obtained free of charge via http://www.ccdc.cam.ac.uk/conts/retrieving.html, or from the Cambridge Crystallographic Data Center, 12 Union Road, Cambridge CB2 1EZ, UK; fax: +44-1223-336-033; or e-mail: deposit@ccdc.cam.ac.uk.

Author Contributions: B.M.; investigation, performed the chemical experiments and data collection, J.R., I.C., and E.L.; investigation, performed cytotoxic experiments using Alamar Blue Assay, Z.R.; investigation, performed cytotoxic experiments using SRB assay and wound healing assay, A.M.C.; investigation, performed cytotoxic experiments on MCF10A cells, G.A.; investigation, performed cytotoxic experiments on MDA-MB-435 and 4T1 cells, A.C.; resources, provided plant material and description, S.D.; formal analysis and supervised the experiments performed by A.M.C., D.M.P.-C.; investigation, performed crystallographic data and formal analysis, E.H.; formal analysis and supervised the experiments performed by G.A., and Z.R., P.V.; formal analysis and supervised the experiments performed by J.R., I.C., and E.L., C.A.O.; supervised, formal analyses, administrated and was in charge of funding acquisition of the project. All authors read and approved the final manuscript.

Funding: Research reported in this publication was supported by a subproject (to C.A.O.) from the Puerto Rico IDeA Networks of Biomedical Research Excellence (INBRE) from the National Institute of General Medical Sciences (NIGMS) of the National Institutes of Health (NIH) under grant number P20GM103475, the National Institutes of Health (MBRS-SCORE NIH/NIGMS SC2GM116712) (E.H.) and the RCMI grant U54 MD007600 (National Institute on Minority Health and Health Disparities) (P.V.). The content is solely the responsibility of the authors and does not necessarily represent the official views of the National Institutes of Health. In addition, the crystallographic analysis was supported by the National Science Foundation under Grant No. 1626103 (D.P.C.).

Acknowledgments: We are thankful to personnel of the PR-INBRE (Puerto Rico Idea Network of Biomedical Research Excellence) Program for administrative and mentoring support. We also acknowledge Melvin de Jesús from UPR-Humacao and personnel from UPR-Cayey and UAGM-Gurabo for technical assistance.

Conflicts of Interest: The authors declare no conflict of interest. 


\section{References}

1. American Cancer Society. Global Cancer Facts \& Figures, 4th ed.; American Cancer Society: Atlanta, GA, USA, 2018; pp. 1-76.

2. Greenwell, M.; Rahman, P.K. Medicinal Plants: Their Use in Anticancer Treatment. Int. J. Pharm. Sci. Res. 2015, 6, 4103-4112. [CrossRef]

3. Shah, U.; Shah, R.; Acharya, S.; Acharya, N. Novel Anticancer Agents from Plant Sources. Chin. J. Nat. Med. 2013, 11, 16-23. [CrossRef]

4. Majolo, F.; Delwing, L.K.D.O.B.; Marmitt, D.J.; Bustamante-Filho, I.C.; Goettert, M.I. Medicinal plants and bioactive natural compounds for cancer treatment: Important advances for drug discovery. Phytochem. Lett. 2019, 31, 196-207. [CrossRef]

5. Desai, A.G.; Qazi, G.N.; Ganju, R.K.; El-Tamer, M.; Singh, J.; Saxena, A.K.; Bedi, Y.S.; Taneja, S.C.; Bhat, H.K. Medicinal plants and cancer chemoprevention. Curr. Drug Metab. 2008, 9, 581-591. [CrossRef] [PubMed]

6. Guo, Z.; Vangapandu, S.; Sindelar, R.W.; Walker, L.A.; Sindelar, R.D. Biologically Active Quassinoids and Their Chemistry: Potential Leads for Drug Design. Curr. Med. Chem. 2005, 12, 173-190. [CrossRef] [PubMed]

7. Hall, I.H.; Liou, Y.F.; Okano, M.; Lee, K.H. Antitumor agents XLVI: In vitro effects of esters of brusatol, bisbrusatol, and related compounds on nucleic acid and protein synthesis of P-388 lymphocytic leukemia cells. J. Pharm. Sci. 1982, 71, 345-348. [CrossRef] [PubMed]

8. Cai, S.J.; Liu, Y.; Han, S.; Yang, C. Brusatol, an NRF2 inhibitor for future cancer therapeutic. Cell Biosci. 2019, 9, 45. [CrossRef] [PubMed]

9. Ren, D.; Villeneuve, N.F.; Jiang, T.; Wu, T.; Lau, A.; Toppin, H.A.; Zhang, D.D. Brusatol enhances the efficacy of chemotherapy by inhibiting the Nrf2-mediated defense mechanism. Proc. Natl. Acad. Sci. USA 2011, 108, 1433-1438. [CrossRef]

10. Blicharska, N.M.; Zhixiu, L. Anti-proliferative effect of Brusatol and Brucein D on human breast cancer cells. J. Undergrad. Life Sci. 2016, 10, 45-49.

11. Alves, I.A.; Miranda, H.M.; Soares, L.A.; Randau, K.P. Simaroubaceae family: Botany, chemical composition and biological activities. Rev. Bras. Farmacogn. 2014, 24, 481-501. [CrossRef]

12. Little, E.L., Jr.; Woodbury, R.O.; Wadsworth, F.H. Trees of Puerto Rico and the Virgin Islands. In United States Department of Agriculture, Forest Service, Agricultural Handbook No. 449; United States Government Printing Office: Washington, DC, USA, 1974; Volume 2.

13. Claudio, K.; Hernández, J.; Rivera, J.; Ortiz, I.; Carvajal, A.; Perez, M.; Pagán, M.; Ospina, C.A. Biological Screening of Select Puerto Rican Plants for cytotoxic and antitumor activities. Proc. R. Health Sci. J. 2015, 34, 25-30.

14. Arisawa, M.; Fujita, A.; Morita, N.; Kinghorn, A.D.; Cordell, G.A.; Farnsworth, N.R. Plant Anticancer Agents XXXV. Further Constituents of Simaba multiflora. Planta Med. 1985, 51, 348-349. [CrossRef]

15. Cabral, J.A.; McChesney, J.D.; Milhous, W.K. A new antimalarial quassinoid from Simaba guianensis. J. Nat. Prod. 1993, 56, 1954-1961. [CrossRef] [PubMed]

16. Cachet, N.; Hoakwie, F.; Bertani, S.; Bourdy, G.; Deharo, E.; Stien, D.; Houel, E.; Gornitzka, H.; Fillaux, J.; Chevalley, S.; et al. Antimalarial activity of simalikalactone E, a new quassinoid from Quassia amara L. (Simaroubaceae). Antimicrob. Agents Chemother. 2009, 53, 4393-4398. [CrossRef] [PubMed]

17. Muhammad, I.; Bedir, E.; Khan, S.I.; Tekwani, B.L.; Khan, I.A.; Takamatsu, S.; Pelletier, J.; Walker, L.A. A New Antimalarial Quassinoid from Simaba orinocensis. J. Nat. Prod. 2004, 67, 772-777. [CrossRef]

18. Samaa, W.; Ajaiyeobab, E.O.; Choudhary, M.I. Larvicidal properties of simalikalactone D from Quassia africana (Simaroubaceae) baill and baill, on the malaria vector Anopheles gambiae. Afr. J. Tradit. Complement. Altern. Med. 2014, 11, 84-88. [CrossRef]

19. O’Neill, M.J.; Bray, D.H.; Boardman, P.; Phillipson, J.D.; Warhurst, D.C.; Peters, W.; Suffness, M. Plants as sources of antimalarial drugs: In vitro antimalarial activities of some quassinoids. Antimicrob. Agents Chemother. 1986, 30, 101-104. [CrossRef]

20. Bertani, S.; Houel, E.; Bourdy, G.; Stien, D.; Jullian, V.; Landau, I.; Deharo, E. Quassia amara L. (Simaroubaceae) leaf tea: Effect of the growing stage and desiccation status on the antimalarial activity of a traditional preparation. J. Ethnopharmacol. 2007, 111, 40-42. [CrossRef] 
21. Houël, E.; Bertani, S.; Bourdy, G.; Deharo, E.; Jullian, V.; Valentin, A.; Chevalley, S.; Stien, D. Quassinoid constituents of Quassia amara L. leaf herbal tea. Impact on its antimalarial activity and cytotoxicity. J. Ethnopharmacol. 2009, 126, 114-118. [CrossRef]

22. Ozeki, A.; Hitotsuyanagi, Y.; Hashimoto, E.; Itokawa, H.; Takeya, K.; de Mello Alves, S. Cytotoxic quassinoids from Simaba cedron. J. Nat. Prod. 1998, 61, 776-780. [CrossRef]

23. Hunter, K.W.; Crawford, N.P.; Alsarraj, J. Mechanisms of metastasis. Breast Cancer Res. 2008, 10, S2. [CrossRef] [PubMed]

24. Jiang, Y.L.; Liu, Z.P. Natural products as anti-invasive and anti-metastatic agents. Curr. Med. Chem. 2011, 18, 808-829. [CrossRef] [PubMed]

25. Parmar, V.S.; Bracke, M.E.; Vanhoecke, B.W.A.; Derycke, L.; Bolca, S.; Possemiers, S.; Heyerick, A.; Stevens, C.V.; Keukeleire, D.D.; Depypere, H.T.; et al. Plant polyphenolics as anti-invasive cancer agents. Anticancer Agents Med. Chem. 2008, 8, 171-185. [CrossRef] [PubMed]

26. Orellana, E.A.; Kasinski, A.L. Sulforhodamine B (SRB) assay in cell culture to investigate cell proliferation. Biol. Protoc. 2016, 6, e1984. [CrossRef]

27. Liang, C.C.; Park, A.Y.; Guan, J.L. In vitro scratch assay: A convenient and inexpensive method for analysis of cell migration in vitro. Nat. Protoc. 2007, 2, 329. [CrossRef] [PubMed]

28. Ayala-Silva, T.; Meerow, A.W.; Goenaga, R.; Irish, B. Ornamental plant germplasm exploration in tropical forests of Puerto Rico. Proc. Fla. State Hort. Soc. 2007, 120, 4-7.

29. Ewel, J.J.; Whitmore, J.L. The ecological life zones of Puerto Rico and the US Virgin Islands. In USDA Forest Service Institute of Tropical Forestry Research Paper ITF-18; Institute of Tropical Forestry: Rio Piedras, Puerto Rico, 1973.

30. Phadke, P.A.; Mercer, R.R.; Harms, J.F.; Jia, Y.; Frost, A.R.; Jewell, J.L.; Bussard, K.M.; Nelson, S.; Moore, C.; Kappes, J.C.; et al. Kinetics of metastatic breast cancer cell trafficking in bone. Clin. Cancer Res. 2006, 12, 1431-1440. [CrossRef]

(C) 2020 by the authors. Licensee MDPI, Basel, Switzerland. This article is an open access article distributed under the terms and conditions of the Creative Commons Attribution (CC BY) license (http://creativecommons.org/licenses/by/4.0/). 